\title{
Assessing the Performance of Factors Affecting the Profitability of the Banking System: Evidence from Kosovo
}

\author{
By Esat A. Durguti ${ }^{1}$, Enver H. Krasniqi ${ }^{3}$, Dea Krasniqi ${ }^{3}$
}

\begin{abstract}
This review done by empirical surveillance observes the significances of a number of the explicit factors of the bank that are matching to bank governance, financial market configuration on one hand, and macroeconomic aspects of the Kosovo bank's performance on another hand. The Management and assessment of Kosovo's bank effectiveness were accomplished through two indicators return on assets (ROA) and return on equity (ROE). To recognize this assessment, the OLS, and Arellano-Bond (GMM) regression method will be applied with the data used from the financial statements of Kosovo banks on a periodical basis over the period 2006-2019. Based on the challenging environments in which the banking system of Kosovo has passed, we have carefully chosen some specific determinants of the banking industry, as well as some of the macroeconomic determinants. The outcomes propose that upcoming studies may contain diverse dynamic models as well as altered dependent and independent features to elucidate the performance of Kosovo banks.
\end{abstract}

Keywords: Bank's profitability, time series, OLS regression, GMM.

\section{Introduction}

In recent years, economic developments and political reforms have a considerable consequence on the banking sector at a worldwide level, and also exclusively countries that are going on the wayside of the transition section. On behalf of the stretch out period of deregulating/decontrolling, globalization and financial innovations the banking sector is taken into consideration to be its favorable period, up to the beginning of the global crisis. And as a result of this crisis, several policymakers and governments of developed countries have been on the lookout to make a general appraisal among the regulatory framework on the regulation of the financial industry. A number of the researcher in their investigation have stressed that the financial system is the core channel of the economic system, consequently, economies with developed financial systems survive the shock of monetary crises easily. Kosovo's financial system is a moderately new system that started operating at the end of '99, nevertheless, before that time there was no modern banking system in Kosovo in terms of providing financial intermediation based on market economy circumstances. The financial sector in Kosovo continues to be characterized by a satisfactory level and stability even during 2019, although total financial sector assets grew

| $1 \mathrm{PhD}$, Professor assistant, Department of Bank, Finance and Accounting, Faculty of Economic, University of Mitrovica.

${ }^{2} \mathrm{PhD}$, Professor assistant, Business and Management Economy, University College of Business and 
at a slower pace. This is created clear by the actual fact that the worldwide crisis appeared with time-scaling shock waves. The first shock wave involved countries with financial systems and cross-cutting to a very high degree, while the latest wave affected countries where the degree of opening and cross-country was relatively small. The potential risks become even sharper for Western Balkan countries, given that the banking systems they have created are relatively new and inexperienced. Kosovo's financial system assets continued its upward trend in 2019, reaching 7.0 bln euros. The banking system remains to own the core consequence on the expansion of the financial system activity, tracked by the pension sector. The progress of the industry assets was usually strong-minded by the intensification within the lending activity that was a result of the augmented demand for loans and improved lending conditions. Ever since 1999 until now, banks in Kosovo have developed in terms of penetration in all regions as well as developing their products mainly due to the very high profit that is present in this sector $(\mathrm{CBK}, 2019)^{1}$. The motivation of this revision is to undertake to acknowledge the impact of determinants correlative to the business of the banking system, likewise as factors that don't seem to be directly dependent on the management of economic institutions, that we have outlined as external factors. In terms of this analysis, we used econometric models, such as the OLS Regression and the Arellano-Bond estimation method, known as the GMM approach. The paper involves reviewing the literature by analyzing explicit literature in this field, research methodology and applied models, findings and results, conclusions and references.

\section{Theoritical Background}

The reviewed literature comprised of comparable approach to classification of analyzed factors by dividing them into two subgroups of that one was outlined as an internal-factors dependent (factors that may be influenced by the decisive person within the bank's structure) and external-factors (defined as being out of bank's management direct influence). Conservative theory and empirical work on bank profitability suggest that bank profitability is determined by various firm-specific, industry-specific and macroeconomic variables (Curak, Poposki \& Pupur 2011). Several, research has been done analyzing single economic area (i.e. country), similar the investigation of (Mamatzakis \& Panagiotis, 2003) which measured the factor-profitability association in Greece, as well as (Saeed, 2014) and (Kosmidou, Pasiouras, Doumpos, \& Zopounidis, 2006) which composed inspected the topic based on data regarding Great Britain. The single-market analysis was productive and allowed to list a significant number of researched countries. (Williams, 2003) focused on Australia, (Naceur \& Goaied, 2001), as well as (Ines, Ben, \& Mhiri, 2013) studied Tunisia, (Gul, Irshad, \& Zaman, 2011) and (Karim, Sami, \& Hichem, 2010) analyzed Pakistan, (Tarus, Chekol, \& Mutwol, 2012) verified Kenya, (Sufian \& Chong, 2008) focused on Philippines and latter (Sufian \& Habibullah, 2009) researched China. The effectiveness factors in the USA were evaluated by (Wheelock and Wilson, 1995), as well as (Miller and Noulas, 1997), Turkey by the author's (Alp, Ban, Demirgüneş, and Kiliç, 1997) even though Switzerland by (Dietrich and Wanzenried, 2011).

Also, a considerable number of studies have been conducted involving states in their

${ }^{1}$ CBK. (2019). Quarterly Assessment of Financial System. 
analyzes (Goddard, Molyneux, Wilson and Takavoli, 2007); (Mendes and Abreu, 2007); (Staikouras and Wood, 2007) where their findings show that interest rates, inflation, and concentration index have a positive impact on return on equity. Otherwise up-to-date revisions on the European Union banking structure by authors (Menicucci and Paolucci., 2016); (Petria, Capraru, and Ihnatov, 2015); as well as for the countries of Central and Eastern Europe (Căpraru \& Ihnatov, 2014). (Durguti, et al., 2014) have analyzed the determinants that influence the profitability of the banking system in Kosovo, covering the period 2006-2016, and according to this study, it has been found that capital-to-asset, management efficiency, and loan loss provision have an impact on bank profitability. (Tmava, et al., 2019) examined the degree of profitability in the banking system of the Western Balkans countries, by examining specific factors such as assets, loans, loans-todeposits, non-performing loans, and interest rates affect the profitability of the Western Balkans, the banking system, in the respective countries. A large number of studies have been conducted on the impact of GDP growth on profitability, the authors (Ben, Ameur and Mhiri, 2013); (Ben, Naceur and Orman, 2011); (Yanikkaya, et al., 2018) in their studies have found that GDP growth is negatively correlated with bank profitability. As well the final variable, inside the context of our analysis to test, is the real exchange rate. (Staikouras and Wood, 2003); (Noman, et al., 2015); and (Islam and Nishiyama, 2016) results conclude that the real exchange rate has a positive impact on bank profitability. In the following, we are going to present the variables within the graph for the periods we have a tendency to applied in the analysis. As mentioned above the data are quarterly covering the period 2006-2019.

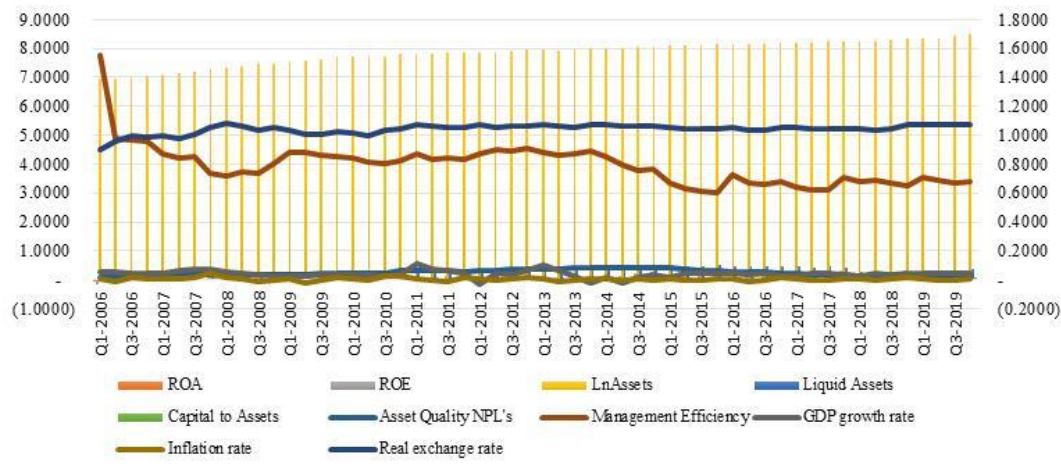

Figure 1: Bank-specific \& macroeconomic factors.

Source: own research

\section{Methodology and Data}

The study includes quarterly cross-sectional time-series data $(\mathrm{n}=\ldots 11$, shows the number of banks ${ }^{2}$ operating in the Kosovo market, where ten of them are with foreign

\footnotetext{
${ }^{2}$ Banks operating in the Kosovo market are: NLB- Nova Ljubjanska Banka, BpB- Bank for Business, Turkiye Cumhuriyeti Ziraat Bankasi, Economic Bank, Raiffeisen Bank Kosovo, ProCredit Bank, TEB BNP Paribas Joint Venture Kosovo, Banka Kombëtare Tregtare, Turkiye Is Bankasi, Komercijalna Banka ad Beograd and Banka Kreditore e Prishtinës receivership office.
} 
capital and only one with local capital.), covering the period from the first quarter of 2006 to the fourth quarter of 2019, reaching 616 observations. The data were provided by the two main agencies, the Central Bank of Kosovo and the Statistical Agency of Kosovo, which are responsible for providing and publishing them in the format specified by the International Monetary Fund. The specific factors of the bank investigated in this study are return on assets, return on equity, the natural logarithm of banking system assets, capital-to-asset, non-performing loans -NPL's, efficiency ratio, while external or macroeconomic factors are GDP growth, inflation rate, and real exchange rate. External factors selected for the study are in relation to various studies conducted in this field, which can be said to be in line with studies by the authors (Athanasoglou, et al., 2008); (Albertazzi and Gambacorta, 2009). In the following, we will present the selected factors for the econometric analysis in tabular form, as well as their impact on profitability.

Table 1: Variable descriptions and expected sign

\begin{tabular}{|c|c|c|c|c|}
\hline Variable & & Denominations & Acronyms & Sign \\
\hline \multirow{2}{*}{ Dependent variable } & \multirow{2}{*}{ Profitability } & Return on assets & $\mathrm{ROA}$ & \\
\hline & & Return on equity & $\mathrm{ROE}$ & \\
\hline \multirow{5}{*}{\multicolumn{2}{|c|}{ Explanatory variables Bank-specific factors }} & Natural logarithm of assets & Lnassets & $++/-$ \\
\hline & & Capital adequacy & Capital-to-assets & + \\
\hline & & Liquidity & Liquid assets & - \\
\hline & & Assets quality & NPL's & $+/-$ \\
\hline & & Management efficiency & Efficiency ratios & - \\
\hline \multirow{3}{*}{\multicolumn{2}{|c|}{ Explanatory variables Macroeconomics factors }} & GDP growth rate & GDP_g & + \\
\hline & & Inflation rate & Inf_r & $+/-$ \\
\hline & & Real exchange rate & RER & - \\
\hline
\end{tabular}

Source: own research

The models applied in this study are OLS regression and General Method of Moments GMM, respectively Arellano-Bond Estimation. The general equations of these approaches are:

$Y_{i t}=\alpha+X_{i t}^{i} \beta\left(\alpha_{i}-\alpha+\varepsilon_{i t}\right)$ - OLS regression

$Y_{\text {lit }}=\mathrm{K}^{\prime} \beta+u_{i, u \sim(0, \Omega)}-$ General Method of Moments

$\mathrm{K} \sim$ is a vector, in which the lagged dependent variable is integrated as a covariate.

Based on the basic formulation of the equation, in our concrete case applying the OLS regression study variables would be:

$\mathrm{ROA}_{\text {it }}=\alpha+\beta_{1}$ (lnassets) $+\beta_{2}$ (liquid assets) $+\beta_{3}$ (capital to assets) + $\beta_{4}(\mathrm{npl}$ 's $)+\beta_{5}$ (management efficiency) $+\beta_{6}$ (gdp growth $)+$ $\beta_{7}$ (inflation rate) $+\beta_{8}$ (real exchange rate) $+\varepsilon_{\text {it }}$

$\mathrm{ROE}_{\text {it }}=\alpha+\beta_{1}$ (lnassets) $+\beta_{2}$ (liquid assets) $+\beta_{3}$ (capital to assets) + $\beta_{4}$ (npl's) $+\beta_{5}$ (management efficiency) $+\beta_{6}$ (gdp growth) + $\beta_{7}$ (inflation rate) $+\beta_{8}$ (real exchange rate) $+\varepsilon_{\text {it }}$ 
The formula according to the dynamic-GMM approach, applying the factors outlined within the $1^{\text {st }}$ difference is:

$\Delta \mathrm{ROA}_{\mathrm{it}}=\alpha+\mu(\mathrm{ROA})_{\mathrm{t}-1}+\alpha+\beta_{1}$ (lnassets) $+\beta_{2}$ (liquid assets) + $\beta_{3}$ (capital to assets) $+\beta_{4}$ (npl's) $+\beta_{5}$ (management efficiency) + $\beta_{6}($ gdp growth $)+\beta_{7}$ (inflation rate $)+\beta_{8}($ real exchange rate $)+\varepsilon_{\text {it }}$

$\Delta \mathrm{ROE}_{\mathrm{it}}=\alpha+\mu(\mathrm{ROE})_{\mathrm{t}-1}+\alpha+\beta_{1}$ (lnassets) $+\beta_{2}$ (liquid assets) + $\beta_{3}$ (capital to assets) $+\beta_{4}$ (npl's) $+\beta_{5}$ (management efficiency) + $\beta_{6}($ gdp growth $)+\beta_{7}$ (inflation rate $)+\beta_{8}($ real exchange rate $)+\varepsilon_{\text {it }}$

Table 2 gives the summary of some statistics which includes mean, median, maximum value, minimum value, standard deviation, skewness, and kurtosis of dependent and independent variables.

Table 2: Summary of descriptive statistics

\begin{tabular}{l|c|c|c|c|c|c|c}
\hline & Obs & Smallest & Largest & Mean & Std.Dev & Skewness & Kurtosis \\
\hline ROA & 616 & -0.0103 & 0.0279 & 0.0109 & 0.0068 & -0.0123 & 3.3838 \\
\hline ROE & 616 & -0.1600 & 0.3457 & 0.1491 & 0.0948 & -0.2288 & 3.5042 \\
\hline Lnassets & 616 & 6.9343 & 8.4671 & 7.8486 & 0.4118 & -0.7167 & 2.5351 \\
\hline Liquid assets & 616 & 0.1686 & 0.5117 & 0.3116 & 0.1099 & 0.6343 & 1.8907 \\
\hline Capital-to-assets & 616 & 0.0606 & 0.0835 & 0.0725 & 0.0055 & -0.0082 & 2.2467 \\
\hline Npl's & 616 & 0.0192 & 0.0871 & 0.0491 & 0.0205 & 0.4082 & 1.9489 \\
\hline Management efficiency & 616 & 0.6053 & 1.5556 & 0.7928 & 0.1458 & 2.4727 & 14.3369 \\
\hline Gdp growth & 616 & -0.0350 & 0.1090 & 0.0397 & 0.0245 & -0.3973 & 5.6409 \\
\hline Inflation rate & 616 & -0.0190 & 0.0441 & 0.0050 & 0.0108 & 0.7271 & 4.9617 \\
\hline Real exchange rate & 616 & 0.8971 & 1.0842 & 1.0413 & 0.0336 & -1.9395 & 7.8897 \\
\hline Soure: own rats
\end{tabular}

Source: own research

Regarding the description of the statistical details generated by the empirical analysis, we can note that the minimum value of return on assets, and return on equity was -0.01 and 0.16 , although the mean value of these two profit indicators was 0.1 and 0.14 . The maximum values achieved for these two indicators were 0.3 and 0.35 with a really small variance. Therefore, supported these descriptive statistics, initial data indicate that the banking industry of Kosovo contains a high degree of profitability. Non-performing loans is a ratio that can be considered as more challenging for banks' management on the one hand, and on the other side of the regulatory authority. NPL's ratio in Kosovo's banking industry reached the highest value of 8.7 percent in 2009, while the lowest value used in 2006 with 1.9. Based on these empirical results, it is noted that financial Institutions in Kosovo are paying particular attention to risk management, and as a result of adequately managing risk, Kosovo has the lowest rate of non-performing loans in the region and beyond. Correlation analysis involves the development of the corresponding graphical illustration of the joint variance of the variables furthermore as the determination of the numerical indicator of power and also the orientation of the correlation between the variables, respectively, the coefficient of correlation. 
Table 3: Correlation matrix

\begin{tabular}{l|c|c|c|c|c|c|c|c|c|c}
\hline & ROA & ROE & LnAssets & LA & CA & NPL's & ME & GDP_g & IR & RER \\
\hline ROA & 1.000 & & & & & & & & & \\
\hline ROE & $.998^{* *}$ & 1.000 & & & & & & & & \\
\hline LnAssets & 0.170 & .179 & 1.000 & & & & & & & \\
\hline LA & $.284^{*}$ & .248 & $.574 * *$ & 1.000 & & & & & & \\
\hline CA & .218 & .100 & .071 & .244 & 1.000 & & & & & \\
\hline NPL's & -.128 & -.163 & .239 & $.457 * *$ & .231 & 1.000 & & & & \\
\hline ME & $-.585^{* *}$ & $-.570^{* *}$ & $-.655^{* *}$ & $-.434^{* *}$ & $-.442^{* *}$ & -.014 & 1.000 & & & \\
\hline GDP_g & .035 & .039 & -.198 & -.225 & -.104 & -.197 & .081 & 1.000 & & \\
\hline IR & .107 & .113 & -.166 & .334 & -.096 & -.073 & .042 & .123 & 1.000 & \\
\hline RER & .154 & .161 & $.682^{* *}$ & $.281^{*}$ & .227 & .421 & -.623 & -.106 & .121 & 1.000 \\
\hline
\end{tabular}

$\left({ }^{* * *}\right),\left({ }^{* *}\right)$ and $(*)$ : significance correlation at the $1 \%, 5 \%$ and $10 \%$.

Source: own research

The outcomes made in our study show that return on assets is positively correlated with return on equity, liquid assets, and management efficiency with a 95 percent and 90 percent significance level, respectively. While the positive but not significant relationship is with these variables: total assets, capital-to- assets, GDP growth, inflation rate, and real exchange rate. The only variable that has an adverse influence on the return on assets is the non-performing loan.

\section{Results and Discussion}

Before discussing the results of the two models applied within the analysis, we tend to conduct several tests to confirm that the information was acceptable and adequate for the regression model and therefore the Arellano-Bond, GMM method. The tests used are Breusch-Pagan / Cook Weisberg for heteroscedasticity, and variance inflation factor VIF for multicollinearity. The obtained outcomes show that the applied evaluation remain acceptable and consistent since the p-value intended for heteroskedasticity test is with probability $>$ chi2 $=[0.000]$ while VIF test mean value there remains of $[2.70]$ which specifies that the data does not have multicollinearity.

Table 4: Estimation of variance inflation factor

\begin{tabular}{l|c|c}
\hline Variable & VIF & 1/VIF \\
\hline Lnassets & 4.07 & 0.245881 \\
\hline Liquid assets & 2.65 & 0.377484 \\
\hline Capital-to-assets & 1.69 & 0.590820 \\
\hline Npl's & 2.62 & 0.381976 \\
\hline Management efficiency & 3.88 & 0.257443 \\
\hline Gdp growth & 1.09 & 0.914148 \\
\hline Inflation rate & 1.26 & 0.794439 \\
\hline Real exchange rate & 4.32 & 0.231380 \\
\hline Mean VIF & $\mathbf{2 . 7 0}$ & \\
\hline
\end{tabular}

Source: own research 
The R2-statement makes clear the effect of the explanatory variables on the dependent variables that in our case R2 is with coefficient of [0.503] or 50.3 percent of the dependent variables drawn throughout the explanatory variables. Also adjusted R2 is with a constant of [0.419] or 41.9 percent of the variables that possess a dissimilarity among the factors. These results from R2 and R2 adjusted are considered to have a moderate impact, and models as such can be considered stable. The more vital test is the F-test that in each models outcomes shows that each one the factors along are significant for the dependent variables with ROA values [5.96]; $\mathrm{P}=0.000$ and $\mathrm{ROE}$ [6.11]; $\mathrm{P}=0.000$. Durbin-Watson test is 2.323 for the OLS Model 1, and 2.299 for the OLS Model 2. On the other hand on behalf of the Arellano-Bond GMM dynamic the Kao-test for cointegration was applied for stationarity.

Table 5: Estimation results OLS and GMM Arellano-Bond.

\begin{tabular}{|c|c|c|c|c|}
\hline \multirow{3}{*}{ Variable } & \multicolumn{2}{|c|}{ OLS regression model } & \multicolumn{2}{|c|}{$\begin{array}{c}\text { General Method of Moments - [GMM] } \\
\text { Arellano-Bond Estimation }\end{array}$} \\
\hline & Model 1 & Model 2 & Model 3 & \begin{tabular}{|c|} 
Model 4 \\
\end{tabular} \\
\hline & ROA & $\mathrm{ROE}$ & ROA $1^{\text {st }}$ lag & ROE 1 ${ }^{\text {st }}$ lag \\
\hline Constant & $\begin{array}{c}.15239719 \\
{[0.003]}\end{array}$ & $\begin{array}{c}2.299972 \\
{[0.001]}\end{array}$ & $\begin{array}{c}.0128154 \\
{[0.904]}\end{array}$ & $\begin{array}{c}.2830577 \\
{[0.843]}\end{array}$ \\
\hline Lnassets & $\begin{array}{c}-.0070867 * * \\
{[0.046]}\end{array}$ & $\begin{array}{c}.0474315^{* * *} \\
{[0.028]}\end{array}$ & $\begin{array}{c}.0135456 \\
{[0.328]}\end{array}$ & $\begin{array}{c}.1743504 \\
{[0.346]}\end{array}$ \\
\hline Liquid assets & $\begin{array}{c}.0141481 \\
{[0.182]}\end{array}$ & $\begin{array}{c}.176405 \\
{[0.225]} \\
\end{array}$ & $\begin{array}{c}.0112237 \\
{[0.517]}\end{array}$ & $\begin{array}{c}.2454171 \\
{[0.297]}\end{array}$ \\
\hline Capital-to-assets & $\begin{array}{c}-.2109213^{* * *} \\
{[0.029]} \\
\end{array}$ & $\begin{array}{c}-5.478546^{* * *} \\
{[0.020]} \\
\end{array}$ & $\begin{array}{c}-.2104652^{* *} \\
{[0.097]}\end{array}$ & $\begin{array}{c}-6.320372^{* * *} \\
{[0.000]}\end{array}$ \\
\hline Npl's & $\begin{array}{c}-.0042139^{* * *} \\
{[0.040]} \\
\end{array}$ & $\begin{array}{c}-.0597712^{* * *} \\
{[0.008]}\end{array}$ & $\begin{array}{c}-.2883388^{* * *} \\
{[0.000]} \\
\end{array}$ & $\begin{array}{c}-4.185704 * * * \\
{[0.000]} \\
\end{array}$ \\
\hline Management efficiency & $\begin{array}{c}-.0453029^{* * *} \\
{[0.000]}\end{array}$ & $\begin{array}{c}-.6677538^{* * *} \\
{[0.000]}\end{array}$ & $\begin{array}{c}-.0305097 * * * \\
{[0.021]}\end{array}$ & $\begin{array}{c}-.3471019 * * \\
{[0.057]}\end{array}$ \\
\hline Gdp growth & $\begin{array}{c}.0073779 \\
{[0.808]}\end{array}$ & $\begin{array}{c}.0494966 \\
{[0.905]}\end{array}$ & $\begin{array}{c}.0205834 \\
{[0.277]}\end{array}$ & $\begin{array}{c}.3854641 \\
{[0.135]}\end{array}$ \\
\hline Inflation rate & $\begin{array}{c}.0688556 \\
{[0.351]}\end{array}$ & $\begin{array}{c}.7942473 \\
{[0.433]}\end{array}$ & $\begin{array}{c}.1023963^{* * *} \\
{[0.028]}\end{array}$ & $\begin{array}{c}1.256209 * * \\
{[0.047]}\end{array}$ \\
\hline Real exchange rate & $\begin{array}{c}-.037997 \\
{[0.388]}\end{array}$ & $\begin{array}{c}-.4234269 \\
{[0.484]}\end{array}$ & $\begin{array}{c}-.0591209 * * \\
{[0.088]}\end{array}$ & $\begin{array}{c}-.6552815 \\
{[0.172]}\end{array}$ \\
\hline Observation & 616 & 616 & 616 & 616 \\
\hline R-squared & 0.5035 & 0.5096 & -- & -- \\
\hline Adj. R-squared & 0.4190 & 0.4261 & -- & -- \\
\hline F-test & {$[5.96] P=0.000$} & {$[6.11] P=0.000$} & -- & -- \\
\hline Wald Chi 2 & -- & -- & [226.02] P>chi2 0.000 & {$[243.27] \mathrm{P}>\operatorname{chi} 20.000$} \\
\hline Durbin-Watson stat & 2.323 & 2.299 & -- & -- \\
\hline Kao test for co-integration & -- & -- & {$[1.608] \mathrm{P}=0.053$} & {$[4.082] \mathrm{P}=0.000$} \\
\hline Model & OLS & OLS & Arellano-Bond GMM & Arellano-Bond GMM \\
\hline
\end{tabular}

Note. $\left({ }^{* *}\right),\left({ }^{* *}\right),\left({ }^{*}\right)$ significant respectively at $0.01,0.05$ and 0.10 percent.

Source: own research

Besides, the results since this analysis are that each one data are stationary within the $\left[1^{\text {st }}\right.$ lagg] first difference. Considering the outcomes of the econometric analysis of the OLS regression shows that the lnassets ratio has a significant adverse influence on return on assets- ROA at 95.0 percent confidence degree meanwhile the value of $\mathrm{P}=0.046$ while the 
return on equity- ROE has a substantial impact on positive signs at 99.9 percent confidence level; since the value of $\mathrm{P}=0.028$. Even so, the marks under the Arellano-Bond GMM model stay contrariwise related to the OLS regression outcomes where lnassets take an effect on bank profitability but not significantly. Outcomes achieved from this revision on the capital-to-asset stand inside the expected framework where the four models applied have a substantial adverse influence on the 99.9 percent confidence level but with different effect coefficients. The highest effect coefficient on return on equity was observed in the dynamic Arellano-Bond GMM approach with a negative constant of -6.3203 and one with high-reliability sign $[\mathrm{P}=0.000]$. This outcome provides us the vital warnings regarding any increase within the request for the capital increase that has an effect on the decrease in profitability. These outcomes are in mark with studies piloted by the authors (Ata, 2009); (Hoffmann, 2011); also (Chronopoulos, et al., 2015). The results of these revisions suggest that there is an adverse link concerning capital-to-asset and profitability. Non-performing loans stand closely linked to risk administration and have an adverse influence on profitability. OLS model for the non-performing loans in relation to the return on assets has an adverse effect with the significant degree of 99.9 percent with a constant 0.004 if we compare this result with model 3, Arellano-Bond GMM sign level is the same with the OLS model but the constant according to GMM is -0.2883 . Whereas, regarding to return on equity - ROE according to OLS model 2, respectively, it has the lowest negative coefficient degree of -0.059 paralleled to the Arellano-Bond estimation approach which has a coefficient of -4.185 . Non-performing loans increase for the reason that of the lack of adequate risk administration and this insufficient administration in a straight line threatens banks profit. Our outcomes are in track with the study accompanied by (Haneef \& Riaz, 2012).

The assumptions of this study are that the banking sector will scale down non-performing loans by applying the best effective practices for risk administration as well as applying the approaches and techniques required by the regulatory authorities and also the Basel Committee- (BIS). Management efficiency- (ME), consumes a significant adverse impact as all models are at the 99.9 percent confidence degree where the values of each model are as follows: OLS model for return on assets ratio with probability scale $[\mathrm{P}=0.000]$, and return on equity ratio is $[\mathrm{P}=0$ 000]. While valuation by Arellando-Bond model for return on assets $[\mathrm{P}=0.021]$; return on equity $[\mathrm{P}=0.057]$. Our findings stand in step with the revision by (Dietrich and Wanzenried, 2011) the authors used the GMM model to investigate which causes contribute to increasing or decreasing bank profit in Switzerland including panel data for 372 commercial banks settled the period 1999 to 2009. The conclusions of this assessment enclose that: capital-to-assets, financing cost, cost-income or management efficiency, increases of deposits, and interest income has a negative effect on bank profit. Recent studies suggest that when dealing with dynamic panel data and to assess their long-term impact it is preferable to apply a GMM method in relation to OLS regression. The reason lies in the fact that OLS does not continuously assess the coefficient if the data have heterogeneity and there remains a bias intended for increasing heterogeneity in the data. Using the Arellano-Bond method its positive side is that it only evaluates the situations of the implied moment in the AR (1) and adequately eliminates heterogeneity. Also, the GMM method sets the additional situations of the moment that may be false. The inflation is comprehended to devise an important consequence on the 
productivity, separately on the ROA. The GMM outcomes for this ratio is at a noteworthy level of $\mathrm{P}=0.047$. The findings are reliable with the authors (Tan and Floros, 2012) explored the profitability of banks in China covered the period 2003-2009, applying the GMM method and set up that employment productivity, stock market expansion, costeffective management and inflation takes a hugely positive effect on banks profit.

\section{Conclusion}

The primary motivation of this examination was to analyze which determinants and with what sings impact on banks profitability may have bank-specific and macroeconomic determinants. The banking business has a fundamental role in financing economic activities and is one of the three main mechanisms of the financial system. Banking profitability research is important for the academic researcher's, for commercial bank management and also for supervision authorities. This revision focused on analyzing contributing determinants that identify external and internal determinants using quarterly data for the period 2006-2019. In this analysis as mentioned earlier in the methodology unit, the two models are used otherwise known as the classical model OLS regression and the Arellano-Bond dynamic model which analyzes the effectiveness of these determinants over a long-run time. The results produced, confirms the expectations expressed during the assessment of the theoretical and empirical literature. Determinants that consume a substantial effect according to the OLS regression model are natural logarithm asset, capital-to-asset, non-performing loans, and efficiency - (EM), while the long-term effects of valuation under the GMM Arellano-Bond model have resulted with important influence in these factors capital-to-assets, non-performing loans, efficiency- (EM), inflation rate, and real exchange rate. In general, based on the outcomes we can conclude that the productivity of banks is more influenced by the internal determinants known as particular determinants of the banking industry concerning the macroeconomic determinants. Of course, the revision has some limitations. The results would be even more consistent and convincing if more observations were available. These issues can be addressed in future studies adding other factors to the analysis.

\section{References}

Albertazzi, U., \& Gambacorta, L. (2009).Bank profitability and the business cycle. Journal of Financial Stability, 5(4),393-409. http://dx.doi.org/10.1016/j.jfs.2008.10.002.

Alp, A., Ban, U., Demirguneş, K., \& Kilic, S. (1997). Internal Determinants of profitability in turkish banking sector. The ISE Review, 12(46), 1-13.

Ata HA. 2009. Kriz sonrası Türkiye'de mevduat bankaları kârlılı̆̆ına etki eden faktörler. İşletme Fakültesi Dergisi 10:2, 137-151.

Athanasoglou, P.P., Brissimis, S.N.,\& Delis, M. (2008).Bank specific, industry specific and macroeconomic determinants of bank profitability. Journal of International Financial Markets, Institutions and Money, 18(2),121-136. http://dx.doi.org/10.1016/j.intfin.2006.07.001.

Ben Ameur, I. and Mhiri, S. (2013), "Explanatory factors of bank performance evidence from Tunisia", International Journal of Economics, Finance and Management, Vol. 2 No. 1, pp. 1-11.

Ben Naceur, S. and Omran, M. (2011), "The effects of bank regulations, competition, and financial reforms on banks' performance”, Emerging Markets Review, Vol. 12 No. 1, pp. 1-20.

Căpraru, B., \& Ihnatov, I. (2014). Banks' Profitability in Selected Central and Eastern European Countries. Procedia Economics and Finance, 16, 587-591. https://doi.org/10.1016/S2212-5671(14)00844-2. 
Chronopoulos DK, Liu H, McMillan FJ, Wilson JO. 2015. The dynamics of US bank profitability. The European Journal of Finance 21:5, 426-443. http://dx.doi.org/10.2139/ssrn.1972835.

Ćuraka, M., Poposkib, K., Pepura, S. (2011), Profitability Determinants of the Macedonian Banking Sector in Changing Environments, Skopje: Published by Elsevier Ltd. https://doi.org/10.2478/cer-2019$\underline{0025}$.

Dietrich A, Wanzenried G. 2011. Determinants of bank profitability before and during the crisis: Evidence from Switzerland. Journal of International Financial Markets, Institutions and Money 21:3, 307-327. http://dx.doi.org/10.2139/ssrn.1370245.

Durguti, Esat. Zhuja, Donika a. Arifi, Ereza. (2014). An Examination of the Net Interest Margin Aas Determinants of Banks' Profitability in the Kosovo Banking System. European Academic Research, 2 (5):6350-6364. https://doi.org/10.13140/RG.2.2.24588.46720.

Goddard, J., Molyneux, P., Wilson, J. O. S., \& Tavakoli, M. (2007). European banking: An overview. Journal of Banking and Finance, 31(7), 1911-1935. https://doi.org/10.1016/i.jbankfin.2007.01.002.

Gul, S., Irshad, F., \& Zaman, K. (2011). Factors affecting bank profitability in Pakistan. The Romanian Economic Journal, (39), 61-87. RePEc:rei:journl:v:14:y:2011:i:39:p:61-87.

Haneef,S., \& Riaz,T. (April 2012). Impact of Risk Management on Non-Performing Loans and Profitability of Banking Sector of Pakistan. International Journal of Business and Social Science, 3(7).

Hoffmann PS. 2011. Determinants of the profitability of the US banking industry. International Journal of Business and Social Science 2:22, 255-269.

Ines, B., Ben, G., \& Mhiri, S. M. (2013). Explanatory Factors of Bank Performance in Tunisia: A Panel Model Approach. Global Journal of Management and Business Research Finance, 13(5).

Islam, M. and Nishiyama, S. (2016), "The determinants of bank profitability: dynamic panel evidence from South Asian countries", Journal of Applied Finance and Banking, Vol. 6 No. 3, p. 77.

Karim, B. K., Sami, B. A. M., \& Hichem, B. K. (2010). Bank-specific, industry-specific and macroeconomic determinants of African Islamic banks' profitability. International Journal of Business and Management Science, 3(1), 39-56. https://doi.org/10.1016/j.intfin.2006.07.001.

Kosmidou, K., Pasiouras, F., Doumpos, M., \& Zopounidis, C. (2006). Assessing performance factors in the UK banking sector: A multicriteria methodology. Central European Journal of Operations Research, 14(1), 25-44. https://doi.org/10.1007/s10100-006-0158-5.

Mamatzakis, E., \& Panagiotis, R. (2003). Determinants of Greek commercial banks, 1989-2000. SPOUDAIJournal of Economics and Business, 53(1), 84-94. http://sro.sussex.ac.uk/id/eprint/40071.

Mendes, V., \& Abreu, M. (2003). Do macro-financial variables matter for european bank interest margins and profitability? EcoMod2003 - International Conference on Policy Modeling, 1-12.

Menicucci, E., \& Paolucci, G. (2016). The determinants of bank profitability: empirical evidence from European banking sector. Journal of Financial Reporting and Accounting, 14(1), 86-115. https://doi.org/10.1108/JFRA-05-2015-0060.

Miller, S. M., \& Noulas, A. G. (1997). Portfolio mix and large-bank profitability in the USA. Applied Economics, 29(4), 505-512. https://doi.org/10.1080/000368497326994.

Naceur, S. Ben, \& Goaied, M. (2001). The determinants of the Tunisian deposit banks' performance. Applied Financial Economics, 11(3), 317-319. https://doi.org/10.1080/096031001300138717.

Noman, A., Chowdhury, M., Chowdhury, N., Kabir, M. and Pervin, S. (2015), "The effect of bank specific and macroeconomic determinants of banking profitability: a study on Bangladesh", International Journal of Business and Management, Vol. 10 No. 6, p. 287.

Petria, N., Capraru, B., \& Ihnatov, I. (2015). Determinants of Banks' Profitability: Evidence from EU 27 Banking Systems. Procedia Economics and Finance, 20, 518-524. https://doi.org/10.1016/S2212$\underline{5671(15) 00104-5 .}$.

Saeed, M. S. (2014). Bank-related, Industry-related and Macroeconomic Factors Affecting Bank Profitability: A Case of the United Kingdom. Research Journal of Finance and Accounting, 5(2), 2222-2847.

Smith, R., Staikouras, C., \& Wood, G. (2003). Non-Interest Income and Total Income Stability. Publication Bank of England. https://doi.org/10.2139/ssrn.530687.

Staikouras, C. and Wood, G. (2003), "The determinants of bank profitability in Europe", International Business and Economics Research Journal, Vol. 3, pp. 57-68.

Sufian, F., \& Chong, R. R. (2008). Determinants of Bank Profitability in a Developing Economy: Empirical Evidence from the Philippines. Asian Academy of Management Journal of Accounting and Finance, 4(2), 91-112. https://doi.org/10.1080/10599230903340205. 
Sufian, F., \& Habibullah, M. S. (2009). Bank specific and macroeconomic determinants of bank profitability: Empirical evidence from the China banking sector. Frontiers of Economics in China, 4(2), 274291. https://doi.org/10.1007/s11459-009-0016-1.

Tan Y, Floros C. 2012. Bank profitability and inflation: the case of China Journal of Economic Studies 39:6, 675-696. https://doi.org/10.1108/01443581211274610.

Tarus, D. K., Chekol, Y. B., \& Mutwol, M. (2012). Determinants of Net Interest Margins of Commercial Banks in Kenya: A Panel Study. Procedia Economics and Finance, 2, 199-208. https://doi.org/10.1016/S2212-5671(12)00080-9.

Tmava, Q., Berisha, F., and Mehmeti, Milaim. (2019). Comperative Analysis of Banking System Profitability in Western Balkan Countries. Journal of Economics and Management Sciences, 2019-06-01. https://doi.org/10.30560/jems.v2n2p33.

Wheelock, D. C., \& Wilson, P. W. (1995). Evaluating the Efficiency of Commercial Banks: Does Our View of What Banks Do Matter? Federal Reserve Bank of St. Louis Review, 77(4), 39-52.

Williams, B. (2003). Domestic and international determinants of bank profits: Foreign banks in Australia. Journal of Banking and Finance, 27(6), 1185-1210. https://doi.org/10.1016/S03784266(02)00251-0.

Yanikkaya, H., Gumus, N. and Pabuccu, Y. (2018), "How profitability differs between conventional and Islamic banks: a dynamic panel data approach”, Pacific-Basin Finance Journal, Vol. 48, pp. 99-111. 